\title{
EEF1AKNMT wt Allele
}

National Cancer Institute

\section{Source}

National Cancer Institute. EEF1AKNMT wt Allele. NCI Thesaurus. Code C156931.

Human EEF1AKNMT wild-type allele is located in the vicinity of $1 \mathrm{q} 24.3$ and is

approximately $32 \mathrm{~kb}$ in length. This allele, which encodes methyltransferase-like protein

13 , plays a role in the modulation of both apoptosis and protein translation. Mutation of the gene is associated with type 26 autosomal recessive deafness. 